\title{
The Structure of the Cytoplasm in the Cells of Alicularia scalaris, Cord.
}

\author{
BY \\ M. F. RIVETT, B.SC. \\ With Plate VI and three Figures in the Text.
}

$7 \mathrm{HE}$ tissues of the foliose liverwort Alicularia scalaris show, in common

1 with many of the Hepaticae, the development of oil-bodies; they are more conspicuous in this particular genus by virtue of their extremely large dimensions and high refractive index. The oil-bodies of the Hepaticae have been described by systematists as an aid to the identification of species; they have been investigated in greater detail by Pfeffer (1), Wakker (2), Zimmermann (3), Raciborski (4), von Küster (5), Garjeanne (6), and the results of these investigations have been shortly summarized in biochemical works such as those of Czapek (7) and Molisch. Since, however, there still remain some doubts and contradictions in these results, particularly in connexion with the origin of the oil-bodies and their relation to the cytoplasm, this further research into the subject was undertaken.

The appearance of the living cells in the fresh mature leaves of Alicularia scalaris has frequently been described; their shape is hexagonal, with rounded angles; the walls slightly thickened; their size is between $25 \mu$ and $3 \circ \mu$; the chlorophyll granules are large and dispersed regularly and closely round the cell-walls; the large oil-bodies, two, three, or four in number (but occasionally more numerous), are suspended in the midst of the cell and occupy the greater part of the cavity; the nucleus is not visible in the living cell (see Text-fig. I).

In a young living leaf, such as the second or third from the growing point, mounted and examined in water, the cells are seen to be very much smaller, about $7 \mu$ or $8 \mu$ in diameter. In the extreme apical and basal cells there is no trace of the oil-bodies, though there are minute refractive granules which appear at first to be of similar material (see Pl. VI, Fig. I). They are continually in motion, revolving and rotating in the substance of the protoplasm. These, however, are found to persist unchanged throughout the development of the cell; they never have any close association with the developing oil-bodies, and contrast with them in their behaviour towards fixing and staining reagents.

[Annals of Botany, Vol, XXXII. No, CXXV\}, April, 1918.] 
In a slightly older cell of the same leaf, the first traces of the oil-bodies (visible in living material) are to be found; they appear as small refractive drops, similar to the minute granules of the smaller cells, but larger in size; they may be scattered throughout the protoplasm or be limited to a small patch in the cell; where they occur they give the cytoplasm an emulsified appearance similar to that of the oil-bodies in Radula complanata. They lie within the protoplasm and do not push through into the developing central vacuole. These oil-drops are in many cells continually in motion, rotating and revolving with the granules first seen in the younger cells, though less rapidly and in a smaller orbit. Owing to the high refractive index of the oil, the actual limits of their margins are obscured and they appear spherical with a dark edge. From their first appearance, their
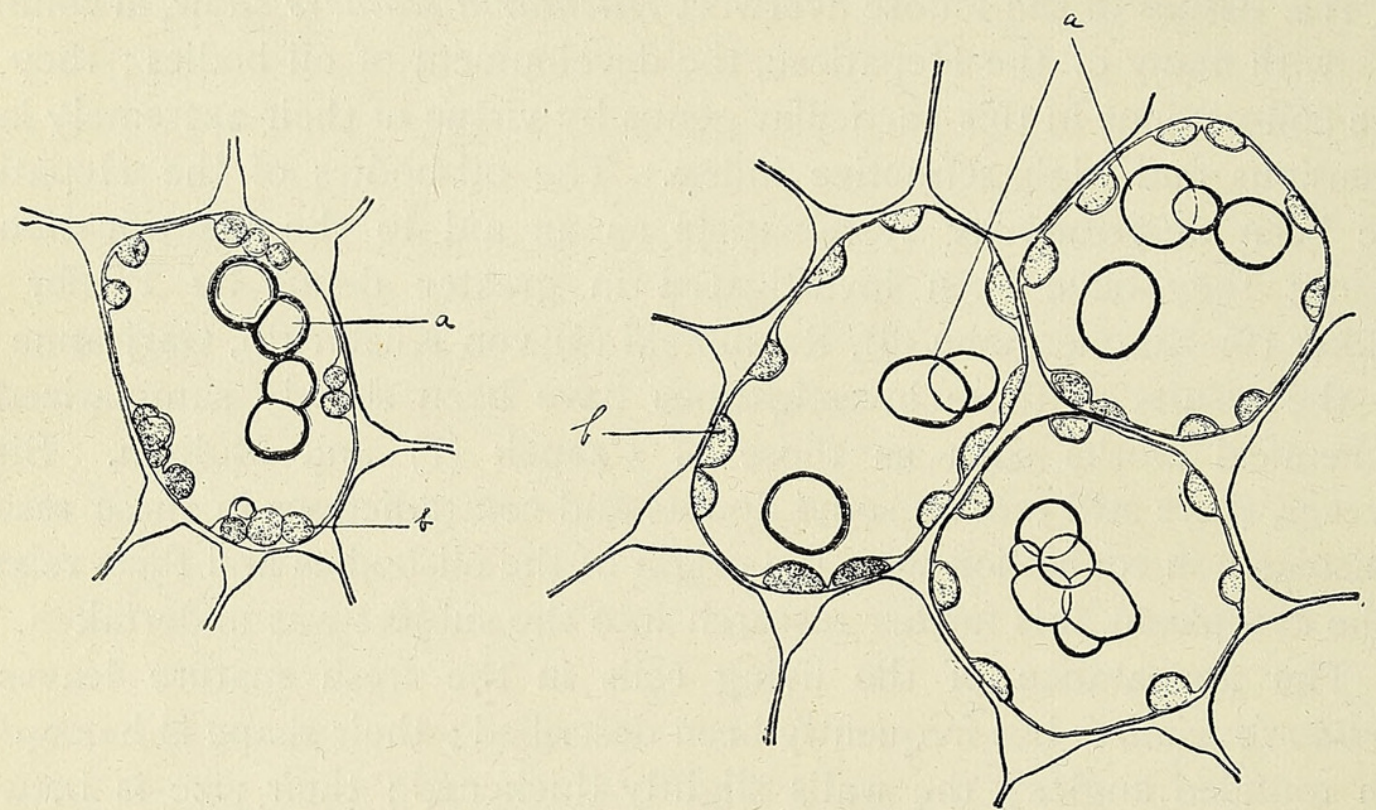

TEXT-FIG. I. Cells taken from mature leaf mounted entire in water and viewed from the surface. $a=$ oil-bodies; $b=$ chlorophyll-granules.

method of movement, they appear simply as drops secreted by the protoplasm within its own substance. There is no specialized external covering visible, for the protoplasmic surface from which they were secreted is blurred by the refractive glimmer of the oil (Pl. VI, Figs. 3 and 4 ).

In a cell which is a little more advanced than the previous one, the oildrops have grown larger and their motion has diminished; a few still appear to rotate slowly, but the revolving movements about the cell have ceased and each drop remains in its own place. In some cells at this stage there are distinctly two patches of oil-drops, foreshadowing the formation of two oil-bodies; but this is not regularly so, and the whole surface of the cell may appear as one emulsified patch. At this stage the central vacuole of the cell is well developed and the protoplasm is retreating towards the cell-wall.

In a cell of an older leaf the central vacuole is nearly fully formed and the pressure exerted on the protoplasm also affects the collection of oil-drops. 
Thus we find that the numerous small drops have coalesced into fewer larger bubbles. These are still within the substance of the protoplasm, separated from the cell-sap by a protoplasmic membrane. This is not visible owing to the refractive glimmer of the oil.

In the mature cells, i. e. those of the fully grown leaves, the large oilbodies are visible. They protrude from some point on the cell-wall into the central vacuole; it is obvious from their position that they are bounded by a surrounding sac of protoplasm which is continuous with the primordial utricle lining the cell-wall. Thus the two secretions of the protoplasm-the cell-sap and the oil-are separated from one another by a partition of the mother substance. In these mature cells there are still to be seen the moving refractive granules found in the youngest living cells.

From these simple observations on the living material but few deductions can be made. There is certainly a suggestion that the oil originates as a general protoplasmic secretion, which appears as a series of bubbles; there is nothing to indicate that any special body (or elaioplast) is associated with each bubble or that the bubbles are localized to any particular part of the protoplasm ; in fact, appearances are rather against such a view, because the numbers and disposition of the first-formed bubbles differ greatly in different cells. On these grounds both the small drops and later the coalesced larger drops can be termed oil-vacuoles, since they are nothing but spaces in the protoplasm filled with the oily liquid. Their formation is quite similar to that of the central vacuole, for the secretion of the drops one by one and the maintenance of their identity for some time are simply due to the physical properties of the liquid oil and its non-miscibility with the more fluid cell-sap; there is nothing to prove that the cell-sap is not secreted drop by drop within the protoplasm and afterwards collected into the large drop which fills the central vacuole. Whether the lining layer of protoplasm in contact with the oil is in any way changed by the contact or by its own act of secretion, so as to form a definite membrane, different in physical and chemical properties from the rest of the cytoplasm, cannot be determined merely by simple observation.

The nature of the oil in the oil-bodies is agreed upon by all investigators as a mixture of an ethereal oil with a small quantity of fatty oil and a proteid substance. This is proved by the action of alcohol, which will, in the cold state and diluted with water, dissolve the greater part of the oil with rapidity. If a leaf is treated with caustic potash, or with a mixture of caustic potash and ammonia, or with a solution of sodium carbonate, the oil-bodies do not lose their refractive properties; i. e. they do not saponify and therefore do not consist mainly of fatty oils. After treatment with alcohol it is always found that there is a small insoluble residuum consisting of an emulsion of small drops with a high refractive index: this seems to be partly a fatty substance and partly proteid. From the homogeneous appearance of the 
fresh oil-bodies, it would seem probable that these substances form a solution with the ethereal oil.

The behaviour of the oil-bodies on treatment with alcohol is interesting and peculiar; if a living leaf is mounted in water, the behaviour can be observed by irrigating with 70 per cent. alcohol under the cover-slip. It has already been described by Garjeanne, Pfeffer, and von Küster. Pfeffer considered that the obvious membrane which is formed around the limits of the oil-body as the oil disappears is a wall or skin different from the surrounding cytoplasm. The wall can be stained with methylene blue and
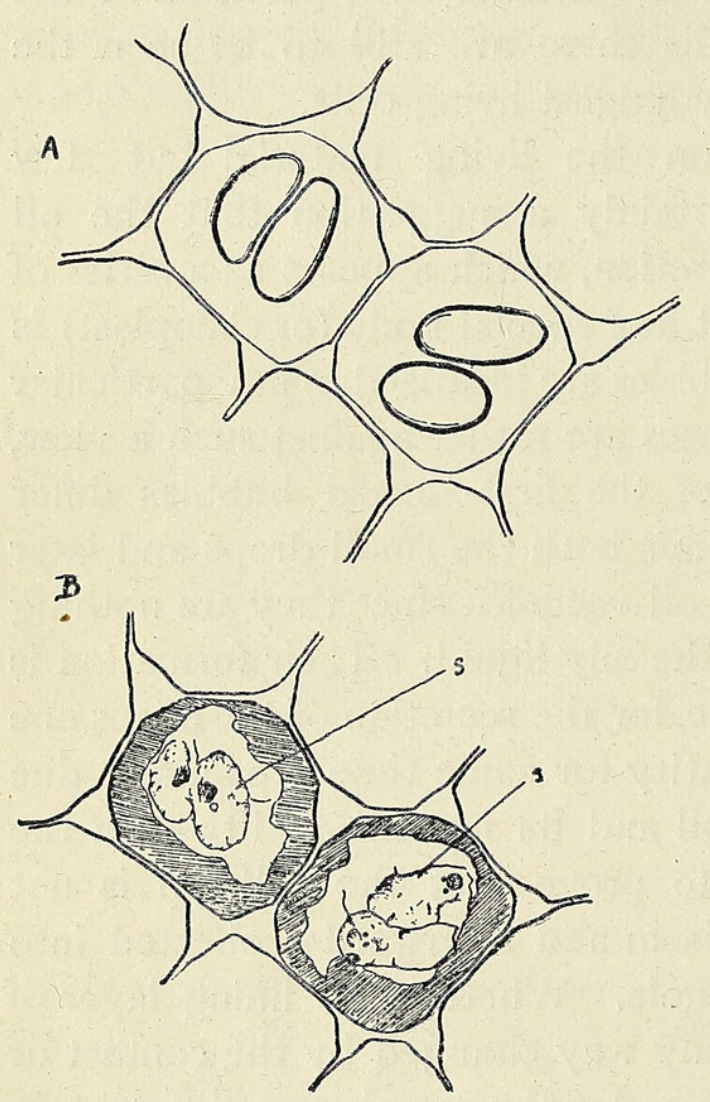

TeXT-FIG. 2. A. Two cells with oilbodies in surface view. B. The same irrigated with alcohol. $s=$ 'sac' of oil-drop. with iodine and looks a very distinct and conspicuous structure (see Textfig. 2). If leaves are mounted in 30 per cent. alcohol, the process of solution of the oil can be observed, as in this strength it takes place slowly. The oil-drop may divide into two, three, or numerous drops, and each of these becomes smaller; or the whole oildrop may rapidly become spherical and gradually contract. The 'membrane' appears around the original limits of the oil-body. If, after the process of solution has gone on for a few moments, the slide is flooded with water, the membrane still appears conspicuous, and the partially dissolved oil-drops remain without further change. The process of solution is never complete in 30 per cent. alcohol.

Von Küster (5), by plasmolysis experiments, satisfied himself that the membrane was an artifact, and by dissolving out the oil in two successive stages, first with weak alcohol and then with strong, showed that two membranes could be formed, one inside the other. Garjeanne (6) showed that the membrane can also be made visible by pressure on the cover-slip, and as a deduction from this in conjunction with von Küster's experiments maintained that the so-called 'wall' (of Pfeffer) is a precipitation membrane formed by the action of the oil on the cell-sap; thus the 'wall' is discovered whenever the protoplasm separating the oil and the cell-sap is destroyed.

It seems to me that unnecessary stress is laid on the point whether the membrane is a differentiated wall or merely a protoplasmic binding. All are agreed that there is a protoplasmic covering round the oil; it is invisible 
when the oil-body is intact owing to the refractive glimmer of the oil ; when this is removed, the membrane shows up, probably with the addition of a slight precipitate; that its surface would be changed by contact with the oil is extremely probable; hence it absorbs a stain with more readiness than the remaining protoplasm. The formation of a second membrane on a second treatment with alcohol does not always take place, and is not nearly so conspicuous as the first, having more the appearance of a deposit of oil in a cavity.

I think we may safely conclude that the particular kind of membrane which is found around the oil-body does not present any argument against the idea that the bodies are vacuoles; the membrane is either the limit of the undifferentiated cytoplasm, or the surface of the cytoplasm slightly changed by contact with the oil. It is not an organ of sufficiently definite morphological and physiological characters to warrant the use of the word 'plastid' in connexion with the oil-bodies.

This simple method of secretion into vacuoles agrees with the fact that the oil is a catabolic waste product. The production is unaffected by any cultural conditions; i. e. by variations in light, temperature, and nutritive materials. It is therefore quite easy to imagine the whole thing as a simple chemical process - the oil-bubbles being given off from the reagents, just as a bubble of gas emerges when an acid touches a metal.

It may be objected that the regularity of form of the mature oil-bodies and the little variation of number in the cells produce a distinctness and individuality which argues against their description as spaces or vacuoles. This objection will certainly have weight with those who have observed the mature bodies only, but it cannot be maintained by those who have observed the emulsion of bubbles, out of which the oil-body arises. The constancy of form of the oil-vacuole is due to the equilibrium between the density of the oil and the density of the surrounding protoplasm. Under certain conditions a bubble can only take up one shape, and it is this which is seen in the constant form of the oil-bodies.

Garjeanne (6) describes the methods which led him to conclude that the oil is secreted in a vacuole; by means of picric acid, which colours the cytoplasm yellow and leaves the spaces uncoloured, he discovered minute vacuoles into which the oil is poured. I have repeated his methods with similar results, but do not place much reliance upon them, since no other fixatives produce the same appearance, and it is obvious that picric acid so rapidly causes change and disorganization in the cytoplasm, that it may easily lead to false conclusions.

The results of irrigating an entire leaf with 2 per cent. osmic acid while under the microscope, and also the investigation of entire leaves fixed in osmic for some hours, confirm the view that the oil is secreted in vacuoles. Both the first-formed drops and the mature oil-bodies stain homogeneously brown and stand out clearly from the surrounding protoplasm. If a series 
of longitudinal sections through the growing point, cut in wax, from material fixed with osmic acid for twenty-four hours, and taken up through alcohol and xylol, are examined on the slide, mounted up in Canada balsam without further staining, then the only cytoplasmic bodies which show up clearly are the refractive granules. They show up as minute black spheres, which are more numerous in the cells of the growing point than in those of the older leaves, though they are still present in the latter. They are arranged in the peripheral layer of the cytoplasm and are also associated with the empty sacs which mark the limits of the oil-bodies. Thus they must be of different material both from the ethereal and fatty oils which disappear in the processes of dehydrating and embedding, even though partially fixed with
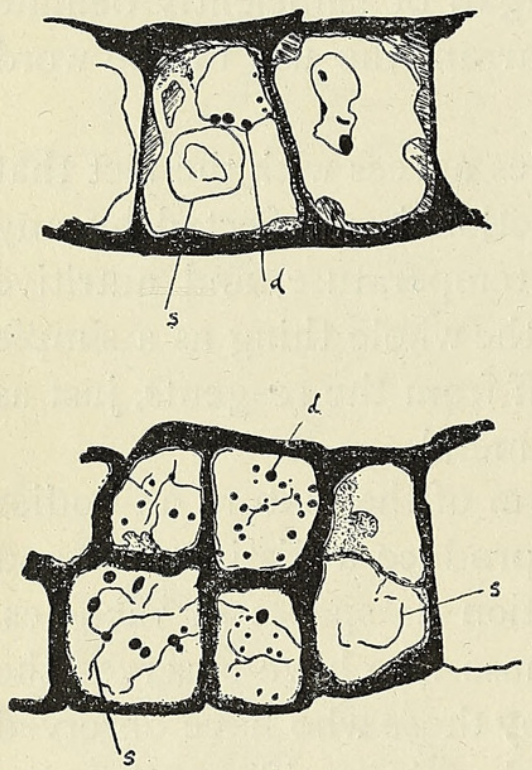

TeXt-Fig. 3. Mature cells in longitudinal section from base of full-grown leaf. $s=$ sacs; $d=$ granules stained with safranin. osmic acid. There is no indication in such an unstained slide of the vacuolar structure of the protoplasm which would indicate the formation of the oil-bodies.

After bleaching with hydrogen peroxide and staining with the triple stain (safranin, gentian violet, and orange G) certain other points emerge. The refractive granules stain brightly with safranin (thus resembling the nucleolus), but they are now much more conspicuous in the older cells than in those nearer the growing point (see Text-fig. 3). They are associated with the empty oil-sacs of the mature cells and are also arranged around the cell-walls. In the growing point they are very much smaller and are frequently masked by the orange colour, which stains the gel material of the cytoplasm. The cells of the growing point are filled with stained contents, which are mainly aggregated in the nucleus, whilst around it is a more or less homogeneous or exceedingly fine granular mass. There is no indication of a spongy network or of a vacuolar structure; the material of the cytoplasm consists of masses of grains so exceeding fine as almost to make up a homogeneous substance. This may be because both the grains and the gel in which they are embedded stain in the same way (see Pl. VI, Fig. $5 \alpha, \mathrm{I}, 2$, and 3 ).

The upper cells of the first two leaves show more differentiated contents; the nucleus still appears large in comparison with the total bulk of the cell and usually occupies a central position. There is a slight indication of vacuolar structure around the nucleus, but in the cells of the third and fourth leaves this is more evident (PI. VI, Fig. $\left.5^{b}, 4\right)$. In between the central nucleus and the peripheral layer of chlorophyll granules there is a vacuolar structure resembling the familiar 'spongy network' of the proto- 
plasm. The spaces of the net are clear, and are separated by threads and wefts of stained material associated with more deeply stained granules. In the cells of fully-grown leaves this structure has disappeared, the protoplasm is restricted to a thin layer, lining the cell-wall, and from this the films or sacs of the oil-bodies stretch into the vacuole. These sacs are distorted and contracted owing to the changes of tension undergone during the embedding process. Around their edges are drops and granules stained brightly with safranin; some of these are undoubtedly the refractive granules of the cytoplasm, others have more the appearance of drops of glistening liquid which have taken up the stain. The appearance of these bodies is very constant in any preparation with the triple stain (see Text-fig. 3 ).

In a series of sections treated with iron-haematoxylon and iron-alum the characters of the cytoplasm become even more distinct. In the apical cell and those adjacent to it, the nuclei with their nucleoli are large blueblack bodies; the surrounding cytoplasm consists of a colourless (i. e. not stained with the haematoxylon) ground in which are numerous small, disconnected bodies, some round and spherical, others thread-like, others irregular, but all are stained deeply grey or black with the haematoxylon. They seem to represent the chondriosomes, or chondriome-structure of the cytoplasm, which has been described in various plant tissues by Schmidt (8), Guilliermond (9), Lewitzky (10), and others. In the upper cells of the second pair of leaves folded around the growing point, the structure is different; around the bulky nucleus is a network formation; the strands of the net are stained deeply grey and the meshes are lighter or colourless; at the crossings of the strands and occasionally around the cell-walls are minute round bodies stained still more deeply. In the next pair of leaves this structure still remains, but in the fourth and succeeding pairs the development of the large central vacuole leaves the cytoplasm only adhering to the cell-walls. In some few cells the nucleus is visible, and in all there is a large development of chloroplasts. Occasionally the 'sacs' of the oilbodies are stained faintly grey, but they do not readily absorb the ironhaematoxylon. Associated with them and occurring also around the cell-walls are round bodies, which are faintly stained and not very conspicuous; these are the bright, refractive bodies of the living protoplasm which stained most clearly with safranin (PI. VI, Fig. 6 and 7).

To sum up shortly the cytoplasmic structure of the leaf-cells :

(i) the actively dividing cells of the growing point and young leaf bases, where the protoplasm fills the whole cell, show a chondriome structure ;

(ii) the maturing cells have a vacuolar protoplasm forming a 'spongy network';

(iii) in the fully-grown cells, the lining layer is so reduced that it serves merely as a covering to its own products. 


\section{Rivett.-The Cytoplasm in the Cells of Alicularia scalaris.}

There is no evidence from my observations to show that the chondriosomes are either transformed directly into plastids by a secretion within their own substance, as has been observed in other plant cells, or that they are the instigators of secretory action on the part of the protoplasm. Nor do my observations suggest that the refractive moving bodies of the living protoplasm are themselves chondriosomes, for their appearance in the stained mature cells is quite different from that of the chondriome in the actively dividing cells. This investigation merely supports the view that the cytoplasm of the actively dividing cells has a chondriome structure and is not a spongy network, though the vacuolar appearance of the older cells might quite well be given that name.

Finally, I wish to express my thanks to Professor J. B. Farmer, F.R.S., both for the suggestion of this research and for the assistance which he has rendered.

\section{BIBLIOGRAPHY.}

1. PFefFer : Über Ölkörper der Lebermoose. Flora, 1874.

2. WAKker : Studien über die Inhaltskörper der Pflanzenzelle. Pringsh. Jahrb., 1888.

3. Zimmermann: Botan. Microtechnik, 1892. Beihefte Bot. Centralbl., I894.

4. RACiborSKI : Anzeig. Akad. Krakau, I893.

5. VON KÜsTER : Die Ölkörper der Lebermoose. Basel, 1894.

6. GaRJEanne: Die Ölkörper der Jungermanniales. Flora, 1903.

7. CzAPek: Biochemie der Pflanzen, I9r 3.

8. E. W. SchmidT : Pflanzliche Mitochondrien. Progressus rei botanicae, r9r3.

9. Guilliermond : Bemerkungen über die Mitochondrien. Berichte der Deutsch. Bot. Gesellsch., I9I 4 .

10. Lewitzky : Die Chondriosomen als Sekretbildner. Berichte der Deutsch. Bot. Gesellsch, I9 2. $8,9,10$. See summary by F. Cavers in the New Phytologist, 1914-1915.

\section{EXPLANATION OF PLATE VI.}

Illustrating Miss Rivett's paper on the Structure of the Cytoplasm in the Cells of Alicularia scalaris, Cord.

Figs. $1,2,3,4$. Very young leaves mounted in water and viewed from the surface, showing early formation of oil-drops.

I. Apex of second leaf : three cells without oil-drops, one cell with oil-drops.

2. Margin of third leaf near base.

3. Margin of third leaf nearer apex.

4. Apex of third leaf.

Figs. 5, 6, 7. Cells from longitudinal sections through the growing point. $5 a$. Apical cell of first and third, $5 b$, of fourth leaf stained with triple stain.

6. Apical cells showing chondriome structure, stained with iron-haematoxylon.

7. Cells from fonth leaf showing vactoles and young chloroplasts. 

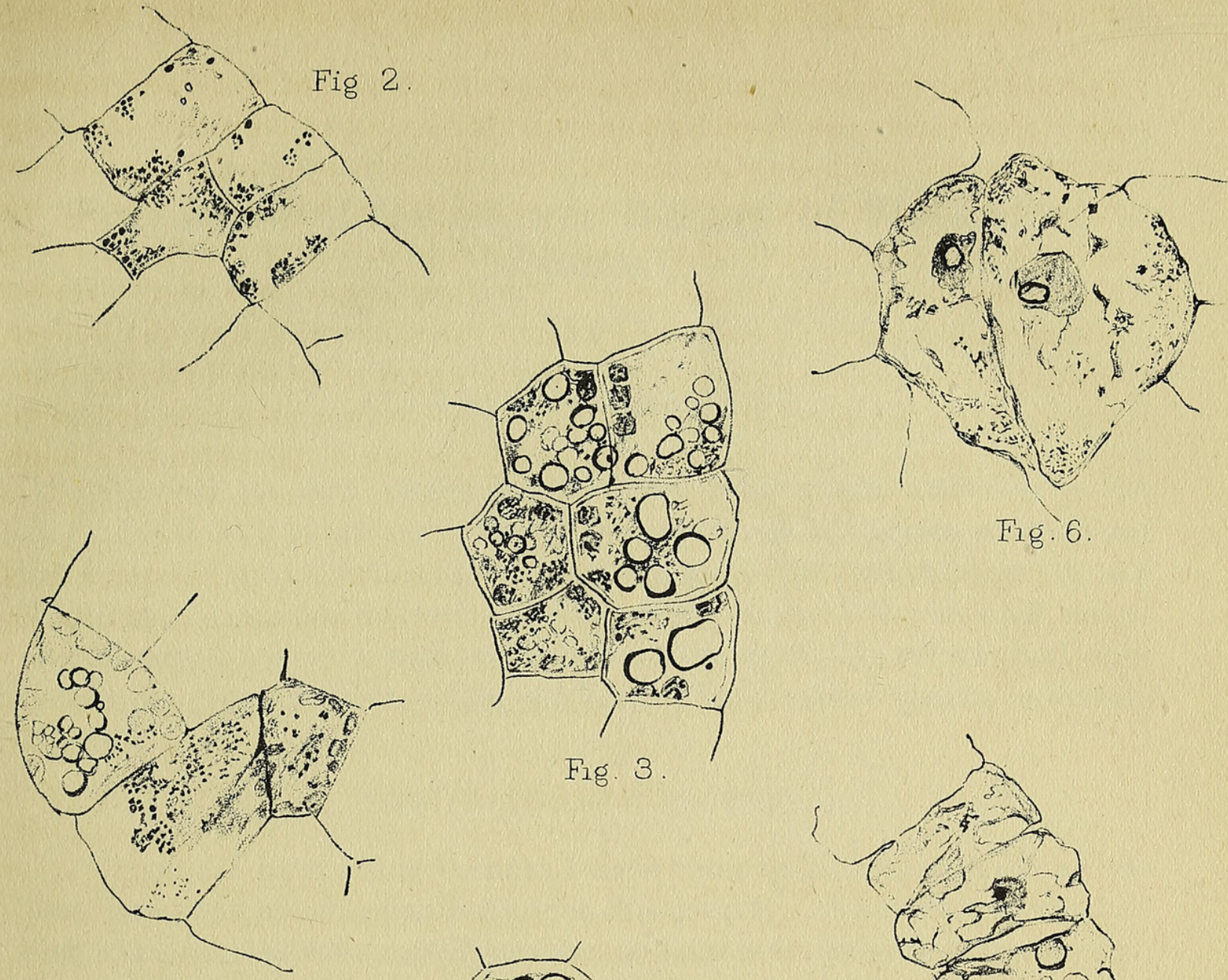

Fig. 3

Fig. 6.
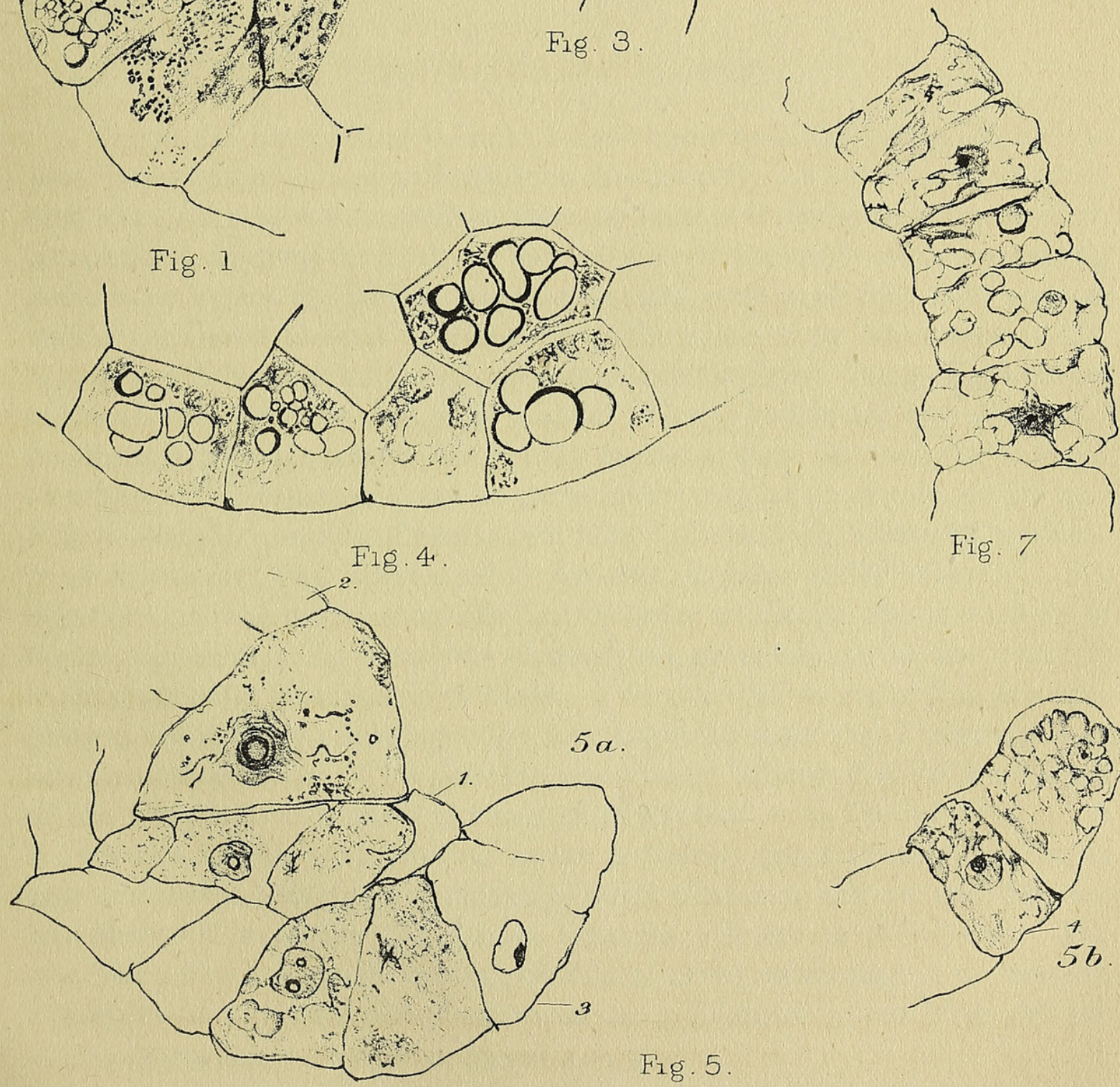

Fig. 7

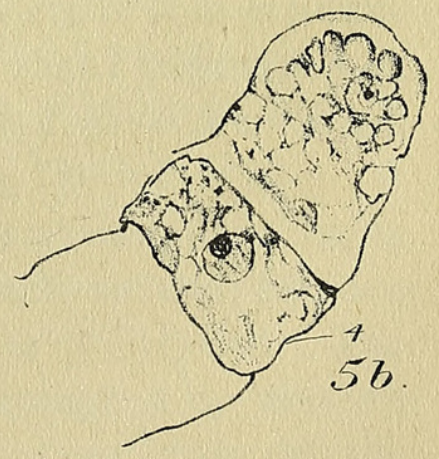

Fig. 5 


\section{$2 \mathrm{BHL}$ Biodiversity Heritage Library}

Rivett, Maud F. 1918. "The structure of the cytoplasm in the cells of Alicularia scalaris, Cord." Annals of botany 32, 207-214.

https://doi.org/10.1093/oxfordjournals.aob.a089671.

View This Item Online: https://www.biodiversitylibrary.org/item/238284

DOI: https://doi.org/10.1093/oxfordjournals.aob.a089671

Permalink: https://www.biodiversitylibrary.org/partpdf/320214

\section{Holding Institution}

Smithsonian Libraries

\section{Sponsored by}

Biodiversity Heritage Library

\section{Copyright \& Reuse}

Copyright Status: Not in copyright. The BHL knows of no copyright restrictions on this item.

This document was created from content at the Biodiversity Heritage Library, the world's largest open access digital library for biodiversity literature and archives. Visit BHL at https://www.biodiversitylibrary.org. 